\title{
Front Matter: Volume 7005
}

, "Front Matter: Volume 7005," Proc. SPIE 7005, High-Power Laser Ablation VII, 700501 (26 June 2008); doi: 10.1117/12.803867

SPIE Event: High-Power Laser Ablation 2008, 2008, Taos, New Mexico, United SPIE. States 


\title{
PROCEEDINGS OF SPIE
}

\section{High-Power Laser Ablation VII}

\author{
Claude R. Phipps
}

Editor

20-24 April 2008

Taos, New Mexico, USA

Sponsored by

SPIE

Cosponsored by

Photonic Associates, LLC (USA)

EOARD—European Office of Aerospace Research \& Development (United Kingdom)

Published by

SPIE

Part One of Two Parts

Volume 7005 
The papers included in this volume were part of the technical conference cited on the cover and title page. Papers were selected and subject to review by the editors and conference program committee. Some conference presentations may not be available for publication. The papers published in these proceedings reflect the work and thoughts of the authors and are published herein as submitted. The publisher is not responsible for the validity of the information or for any outcomes resulting from reliance thereon.

Please use the following format to cite material from this book:

Author(s), "Title of Paper," in High-Power Laser Ablation VII, edited by Claude R. Phipps, Proceedings of SPIE Vol. 7005 (SPIE, Bellingham, WA, 2008) Article CID Number.

ISSN 0277-786X

ISBN 9780819472069

Published by

SPIE

P.O. Box 10, Bellingham, Washington 98227-0010 USA

Telephone +1 3606763290 (Pacific Time) · Fax +1 3606471445

SPIE.org

Copyright (C 2008, Society of Photo-Optical Instrumentation Engineers

Copying of material in this book for internal or personal use, or for the internal or personal use of specific clients, beyond the fair use provisions granted by the U.S. Copyright Law is authorized by SPIE subject to payment of copying fees. The Transactional Reporting Service base fee for this volume is $\$ 18.00$ per article (or portion thereof), which should be paid directly to the Copyright Clearance Center (CCC), 222 Rosewood Drive, Danvers, MA 01923. Payment may also be made electronically through CCC Online at copyright.com. Other copying for republication, resale, advertising or promotion, or any form of systematic or multiple reproduction of any material in this book is prohibited except with permission in writing from the publisher. The CCC fee code is $0277-786 \mathrm{X} / 08 / \$ 18.00$.

Printed in the United States of America.

Publication of record for individual papers is online in the SPIE Digital Library.

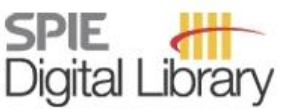

SPIEDigitallibrary.org

Paper Numbering: Proceedings of SPIE follow an e-First publication model, with papers published first online and then in print and on CD-ROM. Papers are published as they are submitted and meet publication criteria. A unique, consistent, permanent citation identifier (CID) number is assigned to each article at the time of the first publication. Utilization of CIDs allows articles to be fully citable as soon they are published online, and connects the same identifier to all online, print, and electronic versions of the publication. SPIE uses a six-digit CID article numbering system in which:

- The first four digits correspond to the SPIE volume number.

- The last two digits indicate publication order within the volume using a Base 36 numbering system employing both numerals and letters. These two-number sets start with 00, 01, 02, 03, 04, 05, $06,07,08,09,0 A, 0 B \ldots 0 Z$, followed by $10-12,20-2 Z$, etc.

The CID number appears on each page of the manuscript. The complete citation is used on the first page, and an abbreviated version on subsequent pages. Numbers in the index correspond to the last two digits of the six-digit CID number. 
This Volume is dedicated to the memory of Arthur Guenther.

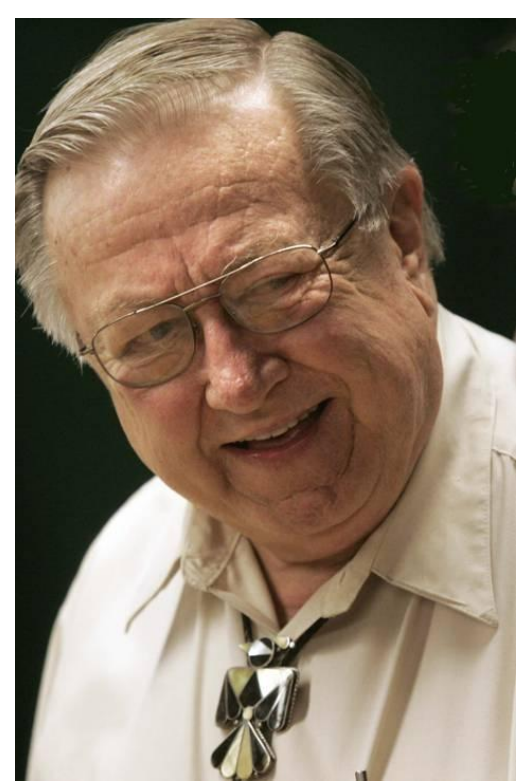

Art Guenther

1931-2007 
Downloaded From: https://www.spiedigitallibrary.org/conference-proceedings-of-spie on 26 Apr 2023

Terms of Use: https://www.spiedigitallibrary.org/terms-of-use 


\title{
Contents
}

\section{Part One}

\author{
xv Conference Committee \\ xvii Introduction
}

\section{SESSION 1 KEYNOTE I}

$700502 \quad$ High speed high precision ablation from ms to fs (Keynote Paper) [7005-02]

R. Poprawe, Fraunhofer Institute of Laser Technology (Germany) and RWTH Aachen (Germany); A. Gillner, D. Hoffmann, Fraunhofer Institute of Laser Technology (Germany); J. Gottmann, RWTH Aachen (Germany); W. Wawers, Fraunhofer Institute of Laser Technology (Germany); W. Schulz, Fraunhofer Institute of Laser Technology (Germany) and RWTH Aachen (Germany)

\section{SESSION 2 SHORT PULSE LASER MATTER INTERACTIONS I}

700504 Femtosecond $x$-ray diffuse scattering measurements of semiconductor ablation dynamics (Invited Paper) [7005-04]

A. M. Lindenberg, Stanford Linear Accelerator Ctr. (USA) and Stanford Univ. (USA);

S. Engemann, K. J. Gaffney, Stanford Linear Accelerator Ctr. (USA); K. Sokolowski-Tinten, Univ. Duisburg-Essen (Germany); J. Larsson, Lund Institute of Technology (Sweden); D. Reis, Univ. of Michigan (USA); P. Lorazo, Ecole Polytechnique de Montreal (Canada); J. B. Hastings, Stanford Linear Accelerator Ctr. (USA)

$700506 \quad$ Ultrashort pulse lasers applied to propulsion/control in space- and atmospheric-flight (Invited Paper) [7005-06]

K. Kremeyer, Physics, Materials and Applied Mathematics Research, L.L.C. (USA)

$700507 \quad$ Ultrafast laser irradiation vs cluster ion impact: molecular-dynamics comparison of materials processes in highly energized solids (Invited Paper) [7005-07]

H. M. Urbassek, C. Anders, L. Sandoval, Technische Univ. Kaiserslautern (Germany); A. K. Upadhyay, Univ. of Michigan (USA)

700508 Implementation of kinetics of phase transitions into hydrocode for simulation of laser ablation [7005-08]

M. E. Povarnitsyn, P. R. Levashov, K. V. Khishchenko, Joint Institute for High Temperatures (Russia)

$700509 \quad$ Nonlinear ultrafast femtosecond X-waves (Invited Paper) [7005-15] J. V. Moloney, M. Kolesik, Univ. of Arizona (USA) and College of Optical Sciences, Univ. of Arizona (USA) 
7005 OB Theoretical models of laser-induced ionization of transparent materials: current issues and recent improvements (Invited Paper) [7005-10]

V. E. Gruzdev, Univ. of Missouri, Columbia (USA)

7005 OC Charging and plasma effects under ultrashort pulsed laser ablation (Invited Paper) [7005-11]

N. M. Bulgakova, A. V. Bulgakov, Institute of Thermophysics (Russia); V. P. Zhukov, Institute of Computational Technologies (Russia); W. Marine, CRMCN, CNRS, Univ. de la Méditerranée (France); A. Y. Vorobyev, C. Guo, The Institute of Optics, Univ. of Rochester (USA)

7005 OE Fabrication of microfluidic networks using a high power femtosecond fiber laser [7005-109] L. Shah, IMRA America, Inc. (USA); D. H. Kam, J. Mazumder, The Univ. of Michigan (USA)

SESSION 4 KEYNOTE II

7005 OF Multi-megajoule NIF: ushering in a new era in high energy density science (Keynote Paper) [7005-01]

E. Moses, Lawrence Livermore National Lab. (USA)

\section{SESSION 5 SHORT PULSE LASER MATTER INTERACTIONS II}

$70050 \mathrm{O}$ On the mechanism of resonant infrared polymer ablation: the case of polystyrene (Keynote Paper) [7005-16]

S. L. Johnson, Vanderbilt Univ. (USA); D. M. Bubb, Rutgers Univ. (USA); K. E. Schriver, R. F. Haglund, Jr., Vanderbilt Univ. (USA)

$70050 \mathrm{~J} \quad$ Correlation between early-stage expansion and spectral emission of a nanosecond laserinduced plasma from organic material [7005-19]

M. Baudelet, M. Boueri, J. Yu, Lab. de Spectrométrie Ionique et Moléculaire, CNRS, Univ. Lyon 1 (France); S. S. Mao, X. Mao, R. E. Russo, Lawrence Berkeley National Lab. (USA)

$7005 \mathrm{OL} \quad$ Formation of grooves in $\mathrm{SiO}_{2}$ coated silicon using femtosecond ytterbium DPSS laser [7005-21]

A. Melninkaitis, Vilnius Univ. (Lithuania); T. Balčiūnas, Vilnius Univ. (Lithuania) and Altechna Co. Ltd. (Lithuania); V. Sirutkaitis, Vilnius Univ. (Lithuania); V. Juzumas, Applied Research Institute for Prospective Technologies (Lithuania) and Vilnius Univ. (Lithuania); J. Janušonis, Applied Research Institute for Prospective Technologies (Lithuania); G. Šlekys, Altechna Co. Ltd. (Lithuania)

\section{SESSION 6 SHORT PULSE LASER MATTER INTERACTIONS III}

7005 OM Ultrafast dynamic ellipsometry of laser ablated silicon (Invited Paper) [7005-22] C. A. Bolme, Massachusetts Institute of Technology (USA); S. D. MCGrane, D. S. Moore, D. J. Funk, Los Alamos National Lab. (USA) 
7005 ON Ultra-short laser interaction with metals and optical multi-layer materials: transport phenomena and damage thresholds (Invited Paper) [7005-23]

T. E. Itina, O. Utéza, N. Sanner, M. Sentis, Lab. of Lasers, Plasmas and Photonic Processing,

CNRS, Univ. de la Méditerranée (France)

700500 Electron generation in laser-irradiated insulators: theoretical descriptions and their application (Invited Paper) [7005-24]

B. Rethfeld, S. Linden, Technische Univ. Kaiserslautern (Germany); L. Englert,

M. Wollenhaupt, L. Haag, C. Sarpe-Tudoran, T. Baumert, Univ. Kassel (Germany)

7005 OP Investigations of the ultrafast laser induced melt dynamics by means of transient quantitative phase microscopy (TQPm) [7005-25]

I. Mingareev, RWTH Aachen Univ. (Germany); A. Horn, Univ. of Kassel (Germany)

\section{SESSION 7 NANOSCALE PHYSICS AND STRUCTURES}

$7005 \mathrm{OQ}$ Industrially scaled pulsed laser deposition based coating techniques for the realization of hemocompatible surfaces for blood contact applications [7005-103]

J. M. Lackner, W. Waldhauser, Joanneum Research Forschungsgesellschaft mbH (Austria);

R. Major, B. Major, Institute of Metallurgy and Materials Science (Poland); E. Czarnowska,

Children's Memorial Health Institute (Poland); F. Bruckert, Institut National Polytechnique de Grenoble, CNRS (France)

7005 OS Laser ablation on nanoscales (Invited Paper) [7005-28]

Z. B. Wang, W. Guo, Univ. of Manchester (United Kingdom); B. S. Luk'yanchuk, Data Storage Institute, Agency for Science, Technology and Research (Singapore); A. Pena, L. Li, Z. Liu, Univ. of Manchester (United Kingdom)

7005 OT Formation of nanoparticles by short and ultra-short laser pulses (Invited Paper) [7005-94] K. Gouriet, T. E. Itina, S. Noël, J. Hermann, M. Sentis, Lab. of Lasers, Plasmas and Photonics Processing, CNRS (France); L. Zhigilei, Univ. of Virginia (USA)

7005 OU Nanopulsed laser modification of Ge/Si heterostructures (Invited Paper) [7005-30]

G. D. Ivlev, E. I. Gatskevich, Institute of Physics (Belarus)

\section{SESSION 8 NOVEL APPLICATIONS IN PHYSICS AND ELECTRONICS}

$70050 \mathrm{X}$ Laser-induced plasma from pure and doped water-ice at high fluence by ultraviolet and infrared radiation (Invited Paper) [7005-33]

J. Schou, Technical Univ. of Denmark (Denmark); A. Matei, Technical Univ. of Denmark (Denmark) and National Institute for Lasers, Plasma and Radiation Physics (Romania);

K. Rodrigo, Technical Univ. of Denmark (Denmark); M. Dinescu, National Institute for Lasers, Plasma and Radiation Physics (Romania)

7005 OY Combinatorial pulsed laser deposition of thin films (Invited Paper) [7005-34]

V. Craciun, National Institute for Lasers, Plasma and Radiation Physics (Romania) and Univ. of Florida (USA); D. Craciun, I. N. Mihailescu, G. Socol, N. Stefan, M. Miroiu, National Institute for Lasers, Plasma and Radiation Physics (Romania); A.-C. Galca, National Institute of Materials Physics (Romania); G. Bourne, Univ. of Florida (USA) 
$70050 Z$ Wall-ablative laser-driven in-tube accelerator (Invited Paper) [7005-35]

A. Sasoh, S. Suzuki, A. Matsuda, Nagoya Univ. (Japan)

700510 First demonstration of photonic laser thruster (PLT) (Invited Paper) [7005-36]

Y. K. Bae, Y.K. Bae Corp. (USA)

700511 Stationary force production: experimental and theoretical investigations (Invited Paper) [7005-37]

V. V. Apollonov, Prokhorov General Physics Institute (Russia)

700512 Materials for laser propulsion: "liquid" polymers (Invited Paper) [7005-38]

T. Lippert, L. Urech, Paul Scherrer Institut (Switzerland); R. Fardel, Paul Scherrer Institut (Switzerland) and Empa (Switzerland); M. Nagel, Empa (Switzerland); C. R. Phipps, Photonic Associates, LLC (USA); A. Wokaun, Paul Scherrer Institut (Switzerland)

SESSION 10 LASER DRIVEN FLYERS AND LASER CLEANING

700513 Pulsed laser cleaning: comparing science with art and cultural heritage applications (Invited Paper) [7005-39]

D. M. Kane, A. J. J. Fernandes, Macquarie Univ. (Australia)

700514 Long pulse laser driven shock wave loading for dynamic materials experiments (Invited Paper) [7005-40]

S. N. Luo, S. R. Greenfield, D. L. Paisley, R. P. Johnson, T. Shimada, D. D. Byler, E. N. Loomis, Los Alamos National Lab. (USA); S. N. DiGiacomo, Los Alamos National Lab. (USA) and Arizona State Univ. (USA); B. M. Patterson, K. J. McClellan, R. M. Dickerson, Los Alamos National Lab. (USA); P. D. Peralta, Arizona State Univ. (USA); A. C. Koskelo, D. L. Tonks, Los Alamos National Lab. (USA)

SESSION 11 PLD, MAPLE, AND PROCESSING OF ADVANCED MATERIALS

700516 Synthesis of multimetallic nanoparticles using a solution-based pulsed laser deposition approach (Invited Paper) [7005-42]

A. T. Sellinger, T. Aburada, J. M. Fitz-Gerald, Univ. of Virginia (USA)

700517 Molecular dynamics simulation study of the ejection of polymer molecules and generation of molecular balloons in matrix-assisted pulsed laser evaporation (Invited Paper) [7005-43] L. V. Zhigilei, E. Leveugle, A. Sellinger, J. M. Fitz-Gerald, Univ. of Virginia (USA)

700518 Designing laser-induced refractive index changes in thermal glasses (Invited Paper) [7005-44]

R. Stoian, A. Mermillod-Blondin, C. Mauclair, N. Huot, E. Audouard, Lab. Hubert Curien, CNRS, Univ. Jean Monnet (France); I. M. Burakov, N. M. Bulgakova, Institute of Thermophysics (Russia); Y. P. Meschcheryakov, Lavrentyev Institute of Hydrodynamics (Russia); A. Rosenfeld, A. Husakou, I. V. Hertel, Max-Born-Institut für Nichtlineare Optik und Kurzzeitspektroskopie (Germany) 
7005 IA Pulsed-laser deposition of $\mathrm{ZnO}$ and related compound thin films for optoelectronics [7005-46]

E. Millon, GREMI, CNRS, Univ. d'Orléans (France); J. Perrière, INSP, CNRS, Univ. Paris VI (France); S. Tricot, C.-B. Boulmer-Leborgne, GREMI, CNRS, Univ. d'Orléans (France)

7005 1B ZnO thin film and nanorod growth by pulsed laser deposition for photonic devices (Invited Paper) [7005-47]

T. Sakano, R. Nishimura, H. Fukuoka, Y. Yata, T. Saiki, M. Obara, Keio Univ. (Japan); H. Kato, M. Sano, Stanley Electric Co., Ltd. (Japan)

\section{SESSION 12 HIGH POWER LASERS APPLICATIONS AND DIAGNOSTICS}

7005 1C Novel aspects in laser propulsion (Invited Paper) [7005-48]

W. L. Bohn, German Aerospace Ctr. (Germany)

7005 IE Lasers in space (Invited Paper) [7005-50]

M. M. Michaelis, Univ. of Kwazulu-Natal (South Africa); A. Forbes, Univ. of Kwazulu-Natal (South Africa) and Council for Scientific and Industrial Research (South Africa); R. Bingham, B. J. Kellett, Rutherford Appleton Lab. (United Kingdom); A. Mathye, Univ. of Kwazulu-Natal (South Africa) and Council for Scientific and Industrial Research (South Africa)

$7005 \mathrm{IF} \quad \mathrm{CO}_{2}$ laser with $65 \mathrm{MW}$ pulses and $100 \mathrm{~kW}$ power: concept and first steps of development (Invited Paper) [7005-51]

D. Schuöcker, B. Holzinger, Vienna Univ. of Technology (Austria)

7005 IG Evaluation of materials for on-board laser diagnostics [7005-52]

J. R. Luke, D. Thomas, The AEgis Technologies Group, Inc. (USA); J. Lewis, RTI International (USA); C. R. Phipps, Photonic Associates, LLC (USA)

\section{Part Two}

SESSION 13 COIL, DOIL, EOIL, AND OTHER UNUSUAL SOURCES

$7005 \mathrm{lH}$ Optimization and scaling of a pulser-sustainer discharge excited oxygen-iodine laser (Invited Paper) [7005-53]

J. Bruzzese, M. Nishihara, A. Hicks, W. R. Lempert, J. W. Rich, I. V. Adamovich, The Ohio

State Univ. (USA)

700511 Latest developments toward the demonstration of a KW-class EOIL laser (Invited Paper) [7005-54]

A. E. Hill, Texas A\&M Univ. (USA) and Plasmatronics, Inc. (USA)

$70051 \mathrm{~J}$ Influence of nitrogen oxides $\mathrm{NO}$ and $\mathrm{NO}_{2}$ additives on singlet oxygen production in pulsed electron-beam sustained discharge (Invited Paper) [7005-55]

A. A. Ionin, Yu. M. Klimachev, A. Yu. Kozlov, A. A. Kotkov, Lebedev Physical Institute (Russia); I. V. Kochetov, A. P. Napartovich, O. A. Rulev, Troitsk Institute for Innovation and Thermonuclear Research (Russia); L. V. Seleznev, D. V. Sinitsyn, N. P. Vagin, N. N. Yuryshev, Lebedev Physical Institute (Russia) 
$70051 \mathrm{~K}$ Optical sources based on a multichannel surface discharge and their application to pump photolytically driven femtosecond XeF(C-A) amplifier (Invited Paper) [7005-56]

V. I. Tcheremiskine, O. P. Uteza, Lab. Lasers, Plasmas et Procédés Photoniques, CNRS, Univ. de la Méditerranée-Aix Marseille II (France); A. Aristov, P.N. Lebedev Physical Institute (Russia); M. L. Sentis, Lab. Lasers, Plasmas et Procédés Photoniques, CNRS, Univ. de la Méditerranée-Aix Marseille II (France); L. D. Mikheev, P.N. Lebedev Physical Institute (Russia)

$70051 \mathrm{~L}$ Improved production of $\mathrm{O}_{2}\left(\mathbf{a}^{1} \boldsymbol{\Delta}\right)$ in transverse radio-frequency discharges (Invited Paper) [7005-57]

B. S. Woodard, J. W. Zimmerman, Univ. of Illinois at Urbana-Champaign (USA);

J. T. Verdeyen, D. L. Carroll, T. H. Field, CU Aerospace (USA); G. F. Benavides, Univ. of Illinois at Urbana-Champaign (USA) and CU Aerospace (USA); A. D. Palla, CU Aerospace (USA);

W. C. Solomon, Univ. of Illinois at Urbana-Champaign (USA)

\section{SESSION 14 OPTICALLY PUMPED LASERS}

$70051 \mathrm{~N}$ Formation of superpower volume discharges and their application for modification of surface of metals (Invited Paper) [7005-59]

V. F. Tarasenko, M. A. Shulepov, Institute of High Current Electronics (Russia)

$7005 \mathrm{IP}$ Optically pumped $\mathrm{HBr}$ gas laser operating in regions of high atmospheric transmission [7005-62]

A. Ratanavis, V. Nampoothiri, N. Campbell, W. Rudolph, Univ. of New Mexico (USA)

$70051 Q \quad$ Efficient and compact short pulse MOPA system for laser-produced-plasma extreme-UV sources employing RF-discharge slab-waveguide $\mathrm{CO}_{2}$ amplifiers [7005-63]

K. M. Nowak, T. Suganuma, A. Endo, A. Sumitani, Extreme Ultraviolet Lithography System Development Association (Japan); D. A. Goryachkin, N. A. Romanov, V. E. Sherstobitov, L. V. Kovalchuk, J.S.C. Laser Physics (Russia); A. Yu. Rodionov, Vavilov Optical Institute (Russia)

\section{SESSION 15 PHYSICS OF LASER MATTER INTERACTIONS}

7005 IR Spectroscopic characterization of ultrashort laser driven targets incorporating both Boltzmann and particle-in-cell models [7005-64]

M. E. Sherrill, J. Abdallah, Jr., G. Csanak, E. S. Dodd, Los Alamos National Lab. (USA);

Y. Fukuda, Y. Akahane, M. Aoyama, N. Inove, H. Ueda, K. Yamakawa, Japan Atomic Energy Research Institute (Japan); A. Ya. Faenov, A. I. Magunov, T. A. Pikuz, I. Yu. Skobelev, VNIIFTRI (Russia)

7005 is Modeling of optical, transport, and thermodynamic properties of Al metal irradiated by intense femtosecond laser pulses [7005-65]

K. V. Khishchenko, M. E. Veysman, N. E. Andreev, V. E. Fortov, P. R. Levashov, M. E. Povarnitsyn, Joint Institute for High Temperatures (Russia)

7005 IT Metal colorization with femtosecond laser pulses (Invited Paper) [7005-66]

A. Y. Vorobyev, C. Guo, The Institute of Optics, Univ. of Rochester (USA) 
$70051 \mathrm{~V}$ Subpicosecond dielectric breakdown and incubation in $\mathrm{Ti}_{\mathrm{x}} \mathrm{Si}_{1-\mathrm{x}} \mathrm{O}_{2}$ composite films with adjustable bandgap [7005-68]

L. A. Emmert, D. Nguyen, I. Cravetchi, M. Mero, W. Rudolph, Univ. of New Mexico (USA);

M. Jupe, M. Lappschies, K. Starke, D. Ristau, Laser Zentrum Hannover e.V. (Germany)

7005 IW Equation of state of matter irradiated by short laser pulse and geometry of spalled cupola [7005-69]

Yu. V. Petrov, L.D. Landau Institute for Theoretical Physics (Russia); V. V. Zhakhovskii, Joint Institute of High Temperatures (Russia) and Osaka Univ. (Japan); N. A. Inogamov,

L.D. Landau Institute for Theoretical Physics (Russia); S. I. Ashitkov, Joint Institute of High Temperatures (Russia); V. A. Khokhlov, L.D. Landau Institute for Theoretical Physics (Russia); A. K. Upadhyay, Univ. of Michigan (USA); M. B. Agranat, Joint Institute of High Temperatures (Russia); S. I. Anisimov, L.D. Landau Institute for Theoretical Physics (Russia); K. Nishihara, Osaka Univ. (Japan); B. Rethfeld, H. M. Urbassek, Univ. Kaiserslautern (Germany)

\section{SESSION 16 LASER SPACE PROPULSION II}

7005 1X Laser-powered multi-newton thrust space engine with variable specific impulse [7005-71] C. R. Phipps, J. R. Luke, Photonic Associates, LLC (USA); W. Helgeson, New Mexico Institute of Mining and Technology (USA)

$70051 Z$ Critical fluence effects in laser propulsion (Invited Paper) [7005-73]

J. E. Sinko, D. A. Gregory, The Univ. of Alabama in Huntsville (USA)

700520 Novel concept of laser-plasma microthruster design [7005-74]

F. N. Ljubchenko, A. V. Fedenev, Central Research Institute of Engineering (Russia);

A. N. Chumakov, N. A. Bosak, B.I. Stepanov Institute of Physics (Belarus); V. F. Tarasenko,

A. N. Panchenko, Institute of High Current Electronics (Russia)

\section{SESSION 17 DPALS I}

700521 Diode pumped alkali lasers (DPALs): an overview (Invited Paper) [7005-75]

W. F. Krupke, WFK Lasers, LLC (USA)

700522 Collisional quenching and radiation trapping kinetics for $\mathrm{Rb}(5 \mathrm{p})$ in the presence of ethane (Invited Paper) [7005-123]

D. A. Hostutler, G. D. Hager, Air Force Research Lab. (USA); M. C. Heaven, Emory Univ. (USA)

700523 Resonance transition 795-nm rubidium laser using He buffer gas (Invited Paper) [7005-77] S. S. Q. Wu, Lawrence Livermore National Lab. (USA) and Univ. of California, San Diego (USA); T. F. Soules, R. H. Page, S. C. Mitchell, V. K. Kanz, R. J. Beach, Lawrence Livermore National Lab. (USA)

\section{SESSION 18 DPALS II}

700524 Alkali lasers development at Laser and Optics Research Center of the U.S. Air Force Academy (Invited Paper) [7005-78]

B. V. Zhdanov, R. J. Knize, U.S. Air Force Academy (USA) 
700525 High power diode pumped alkali vapor lasers (Invited Paper) [7005-79]

J. Zweiback, General Atomics (USA); B. Krupke, WFK Lasers, LLC (USA)

700526 Pressure broadening of the D1 and D2 lines in diode pumped alkali lasers [7005-80]

G. A. Pitz, G. P. Perram, Air Force Institute of Technology (USA)

\section{SESSION 19 DPALS III}

700527 Micro-plasmas as efficient generators of singlet delta oxygen [7005-81]

V. Puech, G. Bauville, B. Lacour, LPGP, CNRS, Univ. Paris-Sud (France); J. Santos Sousa,

LPGP, CNRS, Univ. Paris-Sud (France) and Instituto Superior Técnico (Portugal);

L. C. Pitchford, LAPLACE, CNRS, Univ. Paul Sabatier (France); M. Touzeau, LTM, CNRS, Univ. Joseph Fourier (France)

700528 A quasi-two level analytic model for end pumped alkali metal vapor laser (Invited Paper) [7005-82]

G. Hager, J. Mclver, D. Hostutler, G. Pitz, G. Perram, Air Force Institute of Technology (USA)

700529 Second harmonic operation of diode-pumped Rb vapor lasers (Invited Paper) [7005-83]

A. Petersen, R. Lane, Spectra Physics (USA)

POSTER SESSION

7005 2A Pulsed laser cleaning of aluminium-magnesium alloys: effect of surface modifications on adhesion [7005-86]

M. Autric, Univ. de la Méditerranée, IM2 (France); R. Oltra, Univ. de Bourgogne, Institut Carnot de Bourgogne (France)

$70052 \mathrm{C}$ Organic and inorganic materials analysis by laser-induced breakdown spectroscopy [7005-88]

F. Brygo, J. Hermann, Lab. LP3, CNRS, Univ. Aix-Marseille II (France)

$70052 \mathrm{E}$ Influence of pulsed laser annealing on the properties of Ge quantum dots in Si matrix [7005-93]

E. I. Gatskevich, G. D. Ivlev, Institute of Physics (Belarus); V. A. Volodin, A. V. Dvurechenskii, M. D. Efremov, A. I. Nikiforov, A. I. Yakimov, Institute of Semiconductor Physics (Russia)

$70052 \mathrm{~F}$ Theoretical and experimental study of hydrodynamics of metal target irradiated by ultrashort laser pulse [7005-97]

N. A. Inogamov, S. I. Anisimov, Yu. V. Petrov, V. A. Khokhlov, L.D. Landau Institute for Theoretical Physics (Russia); V. V. Zhakhovskii, Joint Institute of High Temperatures (Russia) and Osaka Univ. (Japan); K. Nishihara, Osaka Univ. (Japan); M. B. Agranat, S. I. Ashitkov, P. S. Komarov, Joint Institute of High Temperatures (Russia)

$70052 \mathrm{G} \quad$ Mode-locked electron-beam sustained discharge CO laser [7005-98]

A. A. Ionin, Y. M. Klimachev, A. A. Kotkov, A. Yu. Kozlov, L. V. Seleznev, D. V. Sinitsyn, Lebedev Physical Institute (Russia)

7005 2J Laser radiation plasma dynamics and momentum coupling (Invited Paper) [7005-70]

J. L. Remo, Harvard Univ. (USA) and Harvard Smithsonian Ctr. for Astrophysics (USA) 
$70052 \mathrm{~L} \quad$ Accumulation effects in laser ablation of metals with high-repetition-rate lasers [7005-105] G. Raciukaitis, M. Brikas, P. Gecys, M. Gedvilas, Institute of Physics (Lithuania)

$70052 \mathrm{M} \quad$ High energy density laser interactions with planetary and astrophysical materials: methodology and data [7005-106]

J. L. Remo, Harvard Univ. (USA), Harvard Smithsonian Ctr. for Astrophysics (USA), and Sandia National Labs. (USA); R. G. Adams, Sandia National Labs. (USA)

$70052 \mathrm{P}$ Reflection Fourier transform infrared spectroscopy of polymer targets for $\mathrm{CO}_{2}$ laser ablation [7005-1 10]

J. E. Sinko, The Univ. of Alabama in Huntsville (USA); C. A. Schlecht, Washington Univ. in St. Louis (USA)

$70052 \mathrm{Q}$ Conical nozzles for pulsed laser propulsion [7005-111]

J. E. Sinko, N. B. Dhote, J. S. Lassiter, D. A. Gregory, The Univ. of Alabama in Huntsville (USA)

$70052 R \quad$ Investigation on momentum coupling coefficient for a parabolic shell [7005-112]

R. Tan, Y. Zheng, C. Ke, K. Zhang, D. Wang, C. Wan, S. Liu, J. Wu, Institute of Electronics (China)

$700525 \quad$ Efficient gas lasers pumped by generators with inductive energy storage [7005-113] V. F. Tarasenko, A. N. Panchenko, A. E. Tel'minov, Institute of High Current Electronics (Russia)

7005 2T Pulsed UV and VUV excilamps [7005-114]

V. F. Tarasenko, M. V. Erofeev, I. D. Kostyrja, M. I. Lomaev, D. V. Rybka, Institute of High Current Electronics (Russia)

$70052 \mathrm{U} \quad$ Magnetic field for efficient exhaustion of $\mathrm{CO}_{2}$ laser-produced Sn plasma in EUV light source [7005-115]

Y. Ueno, G. Soumagne, T. Suganuma, T. Yabu, M. Moriya, H. Komori, T. Abe, A. Endo,

A. Sumitani, Extreme Ultraviolet Lithography System Development Association (Japan)

7005 2V Dynamics of femtosecond laser-induced periodic surface structures on metals [7005-117] J. Wang, C. Guo, The Institute of Optics, Univ. of Rochester (USA)

$70052 \mathrm{~W} \quad$ Space polypropulsion [7005-118]

B. J. Kellett, D. K. Griffin, R. Bingham, Rutherford Appleton Lab. (United Kingdom);

R. N. Campbell, Univ. of Kwazulu-Natal (South Africa); A. Forbes, Univ. of Kwazulu-Natal (South Africa) and Council for Scientific and Industrial Research (South Africa);

M. M. Michaelis, Univ. of Kwazulu-Natal (South Africa)

$70052 Y \quad$ Femtosecond laser milling of ultrathin films of $\mathrm{LiNbO}_{3}$ [7005-122]

O. Gaathon, A. Ofan, J. Dadap, A. Wirthmüller, Columbia Univ. (USA); L. Vanamurthy, S. Bakhru, H. Bakhru, Univ. at Albany (USA); R. M. Osgood, Jr., Columbia Univ. (USA)

Author Index 
Downloaded From: https://www.spiedigitallibrary.org/conference-proceedings-of-spie on 26 Apr 2023

Terms of Use: https://www.spiedigitallibrary.org/terms-of-use 


\title{
Conference Committee
}

\author{
Conference Chair
}

Claude R. Phipps, Photonic Associates, LLC (USA)

Program Committee

Serguey I. Anisimov, L.D.Landau Institute for Theoretical Physics

(Russia)

Victor. V. Appolonov, General Physics Institute (Russia)

Michel L. Autric, Université de la Méditerranée (France)

Dieter Bäuerle, Johannes Kepler Universität Linz (Austria)

Willy L. Bohn, BohnLaser Consult (Germany)

Boris N. Chichkov, Laser Zentrum Hannover e.V. (Germany)

Gordon D. Hager, Air Force Research Laboratory (USA)

Richard F. Haglund, Jr., Vanderbilt University (USA)

Victor H. Hasson, Consultant (USA)

Andrey A. Ionin, P.N. Lebedev Physical Institute (Russia)

Michael L. Lander, General Dynamics Information Technology (USA)

Thomas K. M. Lippert, Paul Scherrer Institut (Switzerland)

Boris S. Luk'yanchuk, Data Storage Institute, Agency for Science, Technology and Research (Singapore)

Max M. Michaelis, University of KwaZulu-Natal (South Africa)

Minoru Obara, Keio University (Japan)

Dennis L. Paisley, Los Alamos National Laboratory (USA)

James P. Reilly, Northeast Science and Technology (USA)

Klaus Sokolowski-Tinten, Universität Duisburg-Essen (Germany)

Michael I. Tribelsky, Moscow Institute of Electrical Engineering and

Technical University (Russia)

Takashi Yabe, Tokyo Institute of Technology (Japan)

\section{Session Chairs}

1 Keynote I

Claude R. Phipps, Photonic Associates, LLC (USA)

2 Short Pulse Laser Matter Interactions I

Max M. Michaelis, University of KwaZulu-Natal (South Africa)

3 Materials Modification and Processing with Ultrashort Pulses

Minoru Obara, Keio University (Japan)

$4 \quad$ Keynote II

Claude R. Phipps, Photonic Associates, LLC (USA) 
$5 \quad$ Short Pulse Laser Matter Interactions II

William P. Latham, Air Force Research Laboratory (USA)

6 Short Pulse Laser Matter Interactions III

Thomas K. M. Lippert, Paul Scherrer Institut (Switzerland)

$7 \quad$ Nanoscale Physics and Structures

Gediminas Raciukaitis, Institute of Physics (Lithuania)

8 Novel Applications in Physics and Electronics

Michel L. Autric, Université de la Méditerranée (France)

9 Laser Space Propulsion

Willy L. Bohn, BohnLaser Consult (Germany)

10 Laser Driven Flyers and Laser Cleaning

Claude R. Phipps, Photonic Associates, LLC (USA)

11 PLD, MAPLE, and Processing of Advanced Materials

Victor Hasson, Consultant (USA)

12 High Power Lasers Applications and Diagnostics

Michael L. Lander, General Dynamics Information Technology (USA)

13 COIL, DOIL, EOIL, and Other Unusual Sources

Carl W. Larson, Air Force Research Laboratory (USA)

14 Optically Pumped Lasers

Andrey A. Ionin, P.N. Lebedev Physical Institute (Russia)

15 Physics of Laser Matter Interactions

Max M. Michaelis, University of KwaZulu-Natal (South Africa)

16 Laser Space Propulsion II

Akihiro Sasoh, Nagoya University (Japan)

17 DPALs I

Gordon D. Hager, Air Force Institute of Technology (USA)

18 DPALS II

Gordon D. Hager, Air Force Institute of Technology (USA)

19 DPALS III

Gordon D. Hager, Air Force Institute of Technology (USA) 


\section{Introduction}

SPIE's International Symposium High Power Laser Ablation VII followed similar symposia held in Taos, Santa Fe and Osaka, beginning in 1998.

This year's Symposium was held 20-24 April 2008 at the Sagebrush Inn, Taos, New Mexico. HPLA VII drew 119 experts in the fields of optics, lasers, and materials. These experts, from 20 countries, presented 88 papers. Two-thirds of the attendees were from outside the U.S.

There were several changes at HPLA this year. For the first time, the Proceedings papers for this conference were refereed. We also welcomed Prof. Drs. Victor Apollonov, Thomas Lippert, Klaus Sokolowski-Tinten, and Michael Tribelsky as new Program Committee members. And, at the Program Committee meeting, we also added Prof. Dr. Baerbel Rethfeld for the 2010 meeting. A hospitality suite was graciously donated for use during the entire conference by Drs. Gordon Lukesh and Susan Chandler of Nukove, Inc., Taos. A small change that the attendees appreciated was that the program ended on Thursday rather than Friday, giving more opportunity to explore New Mexico.

This year, our session topics included short-pulse laser-matter interactions, ultrashort-pulse material modification, nanoscale physics, laser space propulsion, laser-driven flyers, laser cleaning, PLD, MAPLE, high-power lasers and diagnostics, COIL, DOIL, and EOIL lasers, and a completely new session on diode-pumped alkali lasers (DPALs) organized by Gordon Hager and headlined by Bill Krupke.

This wide spectrum continues to be a unique feature of our HPLA symposium series. Our topics are selected not for their connection to a specific technology, (e.g., solid-state lasers), but rather for relevance to the phenomenon of highpower laser ablation and its applications (e.g., laser space propulsion), basic theory, and technology.

A second distinguishing feature of HPLA is the opportunity for technical and social interactions among attendees in a Gordon-like, collegial setting. To enhance this aspect, we continue to avoid parallel sessions and maintain 25-minute invited talks and two-hour lunch breaks. These conditions mean that oral papers are a distinct minority among those given. Consequently, we place great emphasis on the posters, and we continue to offer poster paper awards. A team capably led by Prof. Michaelis selected the three best poster papers, whose authors were recognized at the Wednesday evening banquet.

We enjoyed hearing our keynote speaker, Dr. Ed Moses, director of the National Ignition Facility and Principal Associate Director at Lawrence Livermore Laboratories. 
In the regular program, almost every paper was a highlight in its own way. Rather than attempting to acknowledge the excellent papers in this introduction, I invite you to look over the table of contents in this volume, and read the papers that most interest you.

A highlight of the conference was the Wednesday night dinner, which featured a memorable performance by the Café Cantante Flamenco Ensemble and dance music by the Jimmy Stadler band.

The following people and organizations were crucial to the success of this conference, and deserve great thanks:

Our conference sponsor: SPIE and the very capable SPIE staff.

Our cosponsors: Photonic Associates, LLC and the European Office of Aerospace Research and Development.

Our sister conferences: ISBEP and ICPEPA, who agreed to crosslink their web pages with ours. Prof. Andrew Pakhomov and Leonid Zhigilei deserve our thanks.

Our tireless proceedings referees: Profs. and Drs. Michel Autric, Willy Bohn, Boris Chichkov, Gordon Hager, Richard Haglund, Victor Hasson, Andrei Ionin, Pete Latham, Thomas Lippert, Boris Luk'yanchuk, Max Michaelis, Minoru Obara, Gediminas Raciukaitis, James Reilly, Klaus Sokolowski-Tinten, and Mr. Mike Lander.

And, our very capable Program Committee members:

Sergei Anisimov, L. D. Landau Institute for Theoretical Physics (Russia)

Victor Apollonov, General Physics Institute (Russia)

Michel Autric, Université de la Méditerranée (France)

Dieter Bäuerle, Johannes Kepler Univ. Linz (Austria)

Willy Bohn, BohnLaser Consult (Germany)

Boris Chichkov, Laser Zentrum Hannover (Germany)

Gordon Hager, Air Force Research Laboratory (USA)

Richard Haglund, Jr., Vanderbilt University (USA)

Victor Hasson, Consultant (USA)

Andrei lonin, P.N. Lebedev Physical Institute (Russia)

Michael Lander, General Dynamics Information Technology (USA)

Thomas Lippert, Paul Scherrer Institut (Switzerland)

Boris Luk'yanchuk, Data Storage Institute, ASTAR (Singapore)

Max Michaelis, University of KwaZulu-Natal (South Africa)

Minoru Obara, Keio University (Japan)

Dennis Paisley, Los Alamos National Laboratory (USA)

James P. Reilly, Northest Science and Technology (USA)

Klaus Sokolowski-Tinten, Universität Essen (Germany)

Michael Tribelsky, Moscow Institute of E.E. and Tech. Univ. (Russia)

Takashi Yabe, Tokyo Institute of Technology (Japan) 
Special thanks are given to those members of this committee who suggested, organized, and chaired the sessions in this year's program, ensuring that our program would be the most interesting and most technically advanced of the HPLA series, according to many of our attendees.

Claude R. Phipps 
Downloaded From: https://www.spiedigitallibrary.org/conference-proceedings-of-spie on 26 Apr 2023

Terms of Use: https://www.spiedigitallibrary.org/terms-of-use 